\title{
Effects of muscular endurance training on musculoskeletal disorders in teachers ${ }^{1}$
}

\author{
Efeitos do treinamento de resistência muscular nos \\ sintomas osteomusculares de professoras
}

Elisângela Valevein Rodrigues ${ }^{[a]}$, Anna Raquel Silveira Gomes ${ }^{[b]}$, Ana Tereza Bittencourt Guimarães ${ }^{[c]}$, Bianca Drabovski ${ }^{[b]}$, Rosana Rox ${ }^{[\mathrm{d}]}$, Felipe Santoro Ramos ${ }^{[b]}$, Vera Lúcia Israel ${ }^{[b] *}$

[a] Instituto Federal do Paraná (IFPR), Curitiba, PR, Brazil

[b] Universidade Federal do Paraná (UFPR), Curitiba, PR, Brazil

[c] Universidade Estadual do Oeste do Paraná (Unioeste), Cascavel, PR, Brazil

[d] Instituto Federal de Mato Grosso (IFMT), Juína, MT, Brazil

\section{Abstract}

Introduction: Physical exercise is indicated to reduce the incidence of musculoskeletal symptoms in teachers. Objective: To evaluate the effects of muscular endurance training on muscle strength and musculoskeletal

1 Registro Brasileiro de Ensaio Clínico (REBEC) [Brazilian Registry of Clinical Trials]: RBR-6r7ww5.

* EVR: MSc, e-mail: elisangela.rodrigues@ifpr.edu.br ARSG: PhD, e-mail: annaraquelsg@gmail.com ATBG: PhD, email: anatbguimaraes@gmail.com BD: MSc, e-mail: bibia06@gmail.com RR: grad., e-mail: rosana.rox@jna.ifmt.edu.br FSR: grad., e-mail: felipesantororamos@gmail.com VLI: PhD, e-mail: veral.israel@gmail.com 
symptoms related to the lower limbs of public elementary school teachers. Materials and methods: Thirtyone female teachers were divided into two groups: control ( $\mathrm{CG}, \mathrm{n}=15$ ) and muscular endurance training (TG, $\mathrm{n}=16$ ). The training consisted of two sets of 15 repetitions of exercises for quadriceps and hamstring muscle groups, twice a week, for 7 weeks, which were conducted with $50 \%$ of 10 repetition maximum(10RM) (first to fourth week) and $60 \%$ of 10 RM (fifth to seventh week). Musculoskeletal symptoms (Nordic Musculoskeletal Questionnaire), isometric peak torque (Load cell) and muscle strength (10RM) were assessed before and after intervention. ANOVA for repeated measures and Tukey post hoc were used to analyse strength and peak torque of quadriceps and hamstrings and Chi-square goodness-of-fit test were used to analyse the frequency of occurrence of osteomuscular symptoms. Results: The highest incidence of symptoms was found in the lumbar region in both groups. Training caused increased muscle strength of the quadriceps and hamstrings, but there were no significant differences in either the peak torque in the quadriceps and hamstrings or in the reduction of musculoskeletal symptoms. Conclusion: The exercise program performed in this study increased the dynamic strength in the TG in relation to the $\mathrm{CG}$, but did not alter the incidence of symptoms in the lumbar region and lower limbs in neither of the groups. Thus, results suggest that the duration of intervention may not have been enough to increase peak torque and decrease musculoskeletal symptoms.

Keywords: Work-related musculoskeletal disorders. Teachers. Exercise.

\section{Resumo}

Introdução: A prática de exercício físico é indicada para reduzir a incidência de sintomas osteomusculares em professores. Objetivo: Avaliar os efeitos do treinamento de resistência muscular na força muscular e nos sintomas osteomusculares relacionados aos membros inferiores de professoras do ensino público fundamental. Materiais e métodos: Trinta e uma professoras foram divididas em dois grupos: controle (GC, $n=15)$ e treinamento de resistência muscular (GT, $n=16)$. $O$ treinamento consistiu em 2 séries de 15 repetições de exercícios para quadríceps e isquiotibiais, 2 vezes por semana, durante 7 semanas, sendo realizados com $50 \%$ de 10 Repetições Máximas (10RM) (1a-4a semanas) e com 60\% de 10RM (5a-7a semanas). Os sintomas osteomusculares (Questionário Nórdico), o pico de torque isométrico (célula de carga) e a força muscular (10 RM) foram avaliados antes e após a intervenção. Para a análise estatística foi realizado ANOVA para medidas repetidas, com acompanhamento do teste de Tukey post hoc para força e pico torque de quadriceps e isquiotibiais e o teste de Qui quadrado com bondade de ajuste para a frequência dos sintomas osteomusculares. Resultados: A maior incidência de sintomas foi na região lombar em ambos os grupos. $O$ treinamento promoveu aumento da força muscular de quadríceps e isquiotibiais, porém não houve diferenças significativas tanto no pico de torque isométrico de quadríceps e isquiotibiais quanto na diminuição dos sintomas osteomusculares. Conclusão: o programa de exercícios realizado aumentou a força muscular dinâmica no GT em relação ao GC, porém não alterou a incidência dos sintomas na região lombar e nos membros inferiores em ambos os grupos. Assim, sugere-se que a duração da intervenção pode não ter sido suficiente para gerar o aumento de torque e reduzir os sintomas osteomusculares.

Palavras-chave: Distúrbio osteomuscular relacionado ao trabalho. Professoras. Exercícios.

\section{Introduction}

Work-related musculoskeletal disorders are extremely common and have important consequences for the individual and the society, also can generate high costs for the global economy and can often lead to temporary or permanent disability (1). In Brazil, the changes occurring in the labor organization of elementary school teachers can have contributed to increase diseases that strongly influence the quality of life of these professionals (2).

Repetitive work, intense concentration on the same task for long periods, excessive workload on working and insufficient time to carry out the tasks 
required are among the most stressful factors in teaching (2). In addition, the workplace demands as overload movements and body posture of the teachers, inadequacy on ergonomics of furniture and equipment's can contribute to the development of work-related musculoskeletal disorders (1).

Thus, it is necessary to adopt worker's health prevention policy in order to improve their well being and to avoid the development or aggravation of work-related musculoskeletal disorders.

Accordingly, there is a consensus that physical exercise reduces the incidence of work-related musculoskeletal disorders (1), and that it promotes increase in muscle strength, flexibility and cardiovascular conditioning when conducted at the workplace (3-6).

In Brazil, a high incidence of musculoskeletal symptoms has been observed in elementary school teachers in the shoulder, wrist, neck, dorsal and low back regions, in the knees, ankles and feet (2). Brito et al. (7) observed a high prevalence of sedentary among public school teachers. However, there were no studies that used exercise for preventing and/or treating musculoskeletal disorders related to teaching in elementary schools.

Therefore, it becomes necessary to establish evidence related to the benefits that physical exercise can provide to these teachers. Hence, the aim of this study was to evaluate the effects of muscular endurance training exercises on muscle strength, torque and musculoskeletal symptoms among teachers from public elementary schools.

\section{Materials and methods}

This was a non-randomized, controlled clinical trial with intentional distribution, approved by the Research Ethics Committee of the Health Sciences Division of the Federal University of Paraná (UFPR), as per certificate CAAE: 4184.0.000.091-09. The study was developed in eight municipal elementary schools at the city of Matinhos, Paraná, from March 2010 to December 2011.Sixty-eight teachers in the total of one hundred and nine elementary school teachers in the municipality agreed to participate in this study and signed the Free and Informed Consent Form.

The inclusion criteria were: being as active teachers in the municipal elementary school network, working in classrooms directly with students; having the ability to move around, without additional resources, and to perform the exercises without the need for individual attention; being in good general health and sedentary for at least eight weeks.

The teachers were excluded if they presented and/ or reported a current or previous sickness which preventing the performance of evaluations and/or exercises. Those participating in other programs or activities that included exercise; with incomplete data in the evaluations and those did not wish to perform the exercise protocol were also excluded.

The distribution between groups was done intentionally (8), that is, the teachers chose the group in which they would like to participate. Twenty-eight teachers participated in the Training Group (TG, $\mathrm{n}=28$ ) and sixteen in the Control Group (CG, $\mathrm{n}=16$ ), as demonstrated in the study flowchart (Figure 1).

Of the 68 teachers in total, 24 opted to participate in the first evaluation only. In the TG, 28 began the training, but only 16 completed the entire study. Seven dropped out for personal reasons and five were excluded (one for being hypertensive, two because presented knee pain, one for not properly filling out the Nordic Musculoskeletal Questionnaire and one for not carrying out the quadriceps and hamstring torque peak test). In the CG, one teacher was excluded for presenting labyrinthitis, leaving a total of 15.

\section{Procedures}

The groups were evaluated before (pre) and after (post) seven weeks. Body mass and height (9) were checked for determining the Body Mass Index (BMI) (10), blood pressure (11) and heart rate were also verified (12).

To determine the load for training, load progression, as well as the muscle strength was performed the 10 Repetition Maximum test (10RM) in the pre-period, after the familiarization week (T1), at the end of the fourth week (T4) and in the post-period (13), for the quadriceps and hamstring muscle groups.

The 10RM test evaluates the maximum load that the individual can take in 10 repetitions with a full range of motion of the joint to be tested (14). The test was interrupted at the time the participants failed to perform the complete movement or when occurred concentric voluntary failures in 10RM (15). Before the execution, the teachers were informed about the assessment and training 
routines, which were carried out with adjustable ankle weights. The priority was the correct execution of the movement and the force was obtained in kilograms (kg) (15).

For the evaluation of isometric torque a load cell was used (Kratos brand, model CZAB500). It was used a set of fastening straps, an A/D converter board (National Instruments brand, model NI USB 6218) and an amplifier (Kratos brand, model IK-1C), connected to a computer.

The load cell was fixed to a pole with an adjustable clamp and arranged perpendicularly, both between the iron bar attached to the ground and the longitudinal axis on the tibia of the individuals (16). A test was carried out for the hamstrings and quadriceps with the individuals in the prone and sitting position, respectively. In both tests, the load cell was fixed with the aid of a non-elastic adjustable band with velcro, at the ankle joint, in the opposite direction to the movement. The hip and the ankle were kept at a $90^{\circ}$ angle.

The tests were achieved on the dominant limb, however, the first was executed with the contralateral limb for the purpose of familiarization. The teachers were instructed to perform the movement as fast and hard as possible (16).

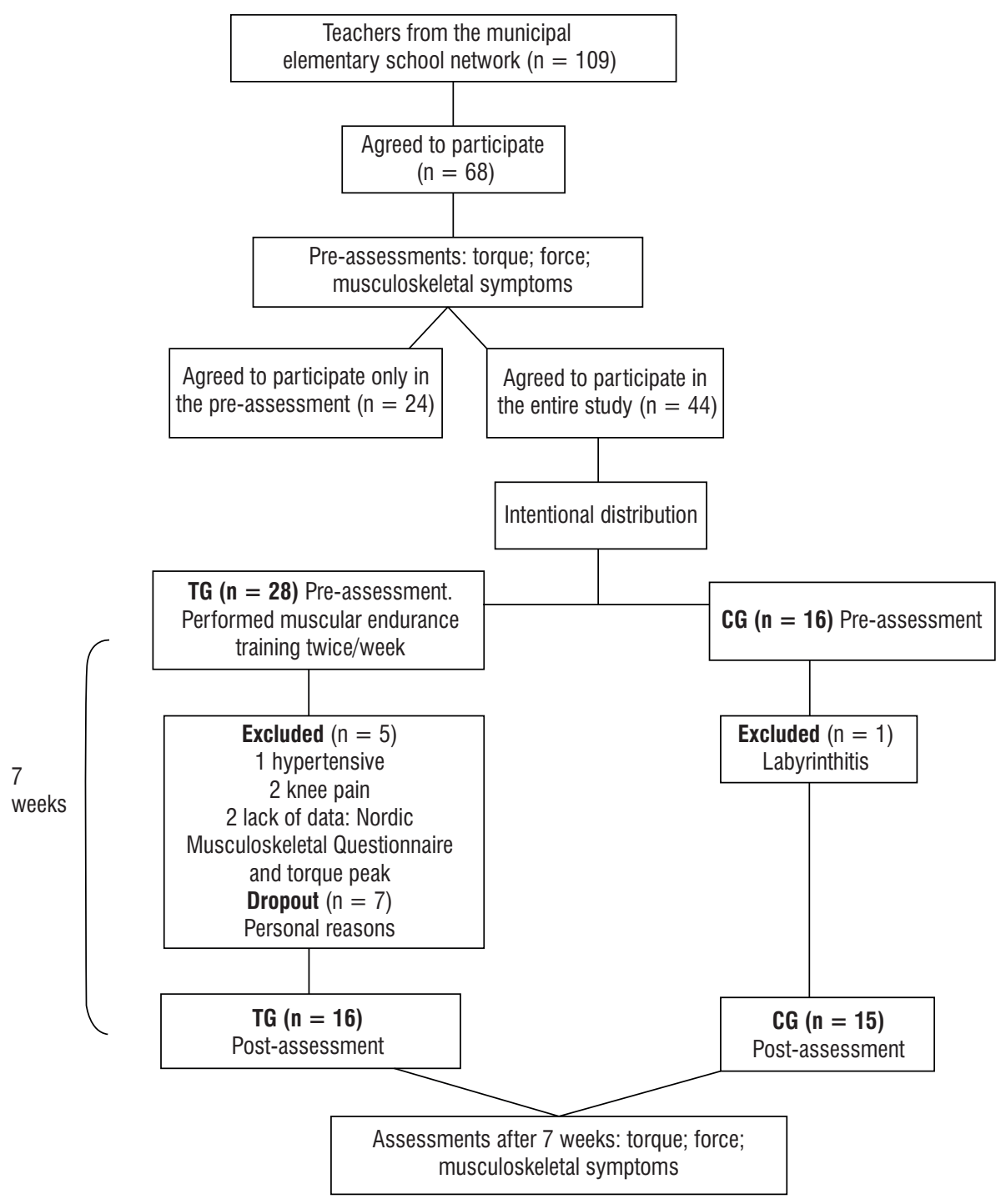

Figure $\mathbf{1}$-Study flowchart 
The data obtained by the load cell were recorded in volts and after converted into units of strength (N) and afterwards this value was multiplied by the distance between the load cell and the central knee joint (in meters), thus the torque in Newton Meters ( $\mathrm{Nm}$ ) was acquired. After converting the values, the peak torque was defined as the maximum peak obtained.

Musculoskeletal symptoms were evaluated by the Nordic Musculoskeletal Questionnaire (17), which consists of multiple-choice items to assess the occurrence of symptoms in nine body regions demonstrated in an anatomical figure and the participants had to answer four questions: if there was symptom in the twelve months and seven days prior to the interview, if the worker was unable to perform the routine activities due to the presence of the symptoms and if the worker needed assistance by a health professional in the past year. This study analyzed only the symptoms related to the lower back region and the lower limbs, within the past seven days to the test.

\section{Local muscular endurance training}

Training was conducted in a group, at the workplace (school) after the work activities, in the afternoon, under the supervision of a physiotherapist. The CG carried out the pre- and post-assessments, but was not involved in the training protocol.

Training sessions were performed twice a week, for seven weeks. Each session lasted on 30 minutes, with 6 minutes of warm-up, 20 minutes of the local muscular endurance exercise for the quadriceps and hamstrings, and 4 minutes of relaxation. For the warm-up, dance activities were carried out, until the participants reached a heart rate between $40-60 \%$ of the heart rate reserve, for six minutes (18).

Then, knee-extension exercise was performed in a sitting position and flexion in the prone position, in the same way that the muscle strength test was performed. This protocol was conducted in accordance with Sjögren et al. (3), adapted for this study.

Two sets of 15 repetitions were performed with one-minute intervals between the sets and with a duration of five seconds in the concentric phase and five seconds in the eccentric phase $(19,20)$. The progression of the training load followed the design for local muscular endurance (19). The exercises were performed with $50 \%$ of $10 \mathrm{RM}$ in the first four weeks and, in the last three weeks, with $60 \%$ of 10RM. The first week was dedicated to the familiarization training.

\section{Analysis of results}

For a sample size of 31 teachers it was assumed the power of 0.92 , with a large size of effect (0.6), a significance level of 0.02 and beta equal to 0.08 .

The data related to the strength and peak torque of the quadriceps and hamstrings were analyzed using ANOVA for repeated measures, thus assuming the sample randomization and, therefore, the greatest power of analysis through the application of parametric tests (21). In case of statistical significance, the Tukey post hoc was applied for unequal samples by testing hypotheses for equality between the groups (TG and CG) in each period of assessment.

Absolute and relative frequencies of occurrence of symptoms were evaluated in the last seven days prior to test in the following body regions: lower back, hips/thighs, knees and ankles/feet. The frequencies observed in the TG, in both the pre- and post-intervention periods, were compared with the frequencies observed in the CG, using the Chi-square goodness-of-fit test. In all statistical tests, significance was set at 0.05 .

\section{Results}

The mean age of the CG was $42 \pm 9$ years and the TG was $39 \pm 8$ years. From a total of 109 teachers, 31 were included, which reflects $28 \%$ of compliance.

In BMI variables, heart rate, and systolic and diastolic blood pressure, differences between the groups were not observed in any of the evaluation periods $(\mathrm{p}>0.05)$.

Regarding to the strength of the quadriceps, significant differences were observed between the groups over the experimental periods $\left(\mathrm{F}_{3.87}=19.428 ; \mathrm{p}=0.0001\right)$. The TG gradually increased the strength values, presenting significant differences, comparing the T4 period to the previous periods $(\mathrm{p}<0.05)$. When comparing the groups, the mean observed in the TG post-period was significantly higher than the mean observed in all other periods in the $C G(p<0.05)$ (Figure 2$)$. 

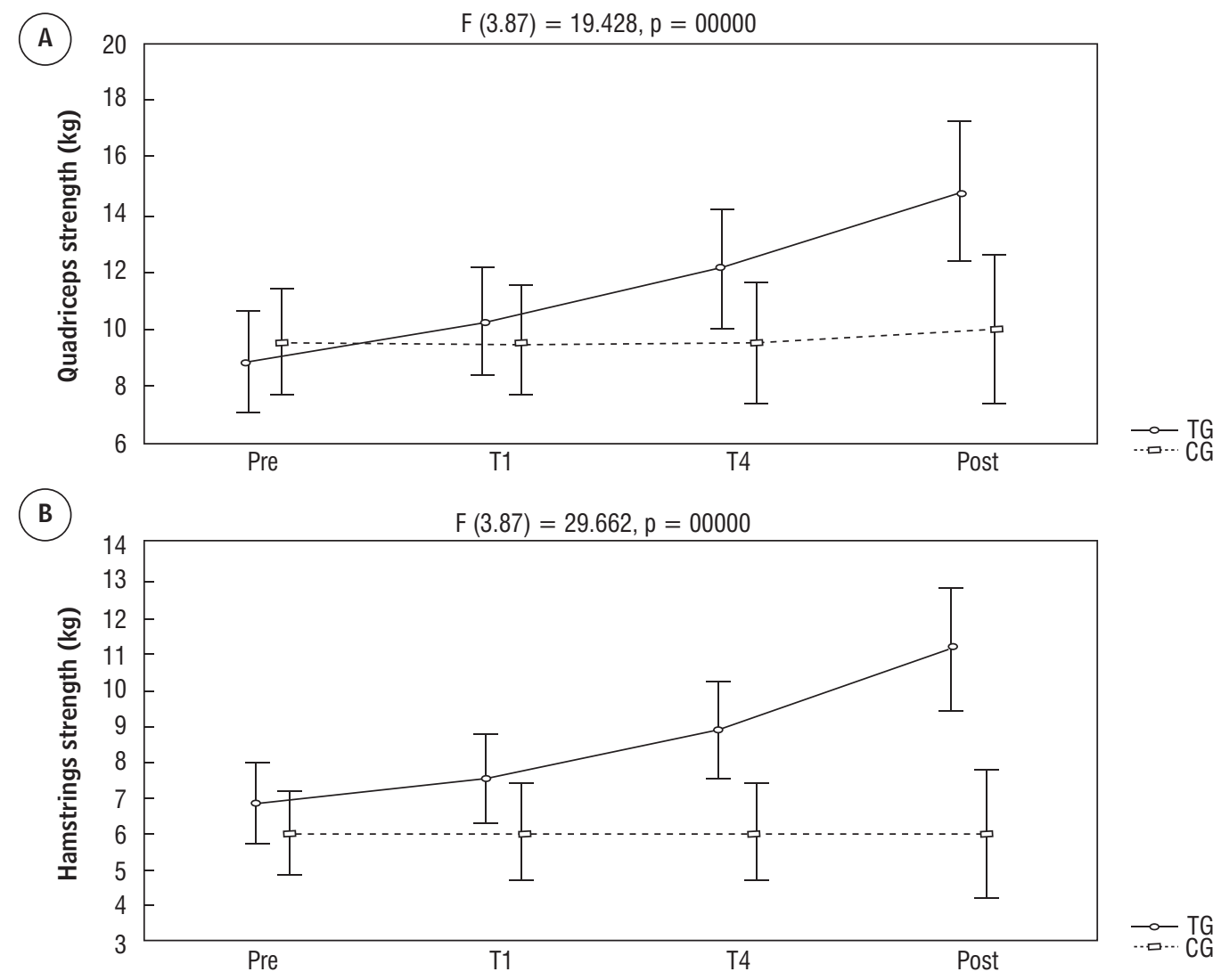

Figure 2 - Mean and confidence interval for the strength of the quadriceps $(A)$ and hamstrings (B)

Note: $\mathrm{TG}=$ Training Group (solid line); $\mathrm{CG}=$ Control Group (dotted line); Pre = pre-training period; $\mathrm{T} 1=$ after the familiarization week; $\mathrm{T} 4=$ four weeks after the start of intervention; Post = post-training period.

Concerning to the strength of the hamstrings, there were significant differences between the groups and over the experimental periods $\left(\mathrm{F}_{3.87}=29.662 ; \mathrm{p}=\right.$ $0.000)$. In the $T G$, there was a significant increase in means from the $\mathrm{T} 4$ period $(\mathrm{p}<0.05)$, rising up to the post-period $(\mathrm{p}<0.05)$. In the $\mathrm{CG}$, there were no significant differences over the experimental period ( $p>0.05$ ). When comparing the two groups over the periods, the mean post-intervention period for the TG group was significantly higher than in all other periods of the CG $(\mathrm{p}<0.05)$ (Figure 2$)$.

Regarding to the peak torque of the quadriceps and hamstrings, there were no significant differences between the groups, and there were no differences in relation to the experimental periods (Table 1).

In the evaluation of musculoskeletal symptoms in the seven days prior to the assessments, there were no significant differences when comparing the TG to the CG (Before $\chi^{2}=2.93, \mathrm{p}=0.403$; After $\chi^{2}=5.66, \mathrm{p}=$ 0.130 ), as well as no differences being observed in intra-group statistics (TG $\chi^{2}=1.64, p=0.201 ; \mathrm{CG} \chi^{2}=$ 1.69, $\mathrm{p}=0.194$ ) (Figure 3).

\section{Discussion}

This study evaluated the influence of local muscular endurance training for the quadriceps and hamstrings groups, on muscle strength, torque and musculoskeletal symptoms in sedentary teachers from public elementary schools. It was found that the training promoted in $\mathrm{TG}$ an increase in the strength of the quadriceps (67\%) and hamstrings (53\%) in relation to the control group. 
Table 1 - Descriptive statistics of quadriceps and hamstring peak torque in the groups

\begin{tabular}{|c|c|c|c|c|c|}
\hline Peak Torque & Periods & Groups & Mean & Standard Deviation & $\mathrm{Cl} 95 \%$ \\
\hline \multirow{4}{*}{$\begin{array}{l}\text { Quadriceps } \\
\text { (Nm) }\end{array}$} & \multirow[b]{2}{*}{ Pre } & TG & 88.23 & 21.20 & $76.93-99.52$ \\
\hline & & CG & 95.57 & 31.04 & $78.38-112.76$ \\
\hline & \multirow[b]{2}{*}{ Post } & TG & 86.12 & 18.85 & $76.07-96.16$ \\
\hline & & CG & 87.25 & 29.63 & $70.84-103.66$ \\
\hline \multirow{4}{*}{$\begin{array}{l}\text { Hamstrings } \\
(\mathrm{Nm})\end{array}$} & \multirow{2}{*}{ Pre } & TG & 30.22 & 5.48 & $27.30-33.14$ \\
\hline & & $C G$ & 32.00 & 10.41 & $26.23-37.76$ \\
\hline & \multirow[b]{2}{*}{ Post } & TG & 31.04 & 9.36 & $26.05-36.03$ \\
\hline & & CG & 32.91 & 10.10 & $27.32-38.50$ \\
\hline
\end{tabular}

Note: $\mathrm{TG}=$ Training Group; $\mathrm{CG}=$ Control Group; Pre = pre-training period; Post = post-training period; $\mathrm{Cl}=$ Confidence interval.

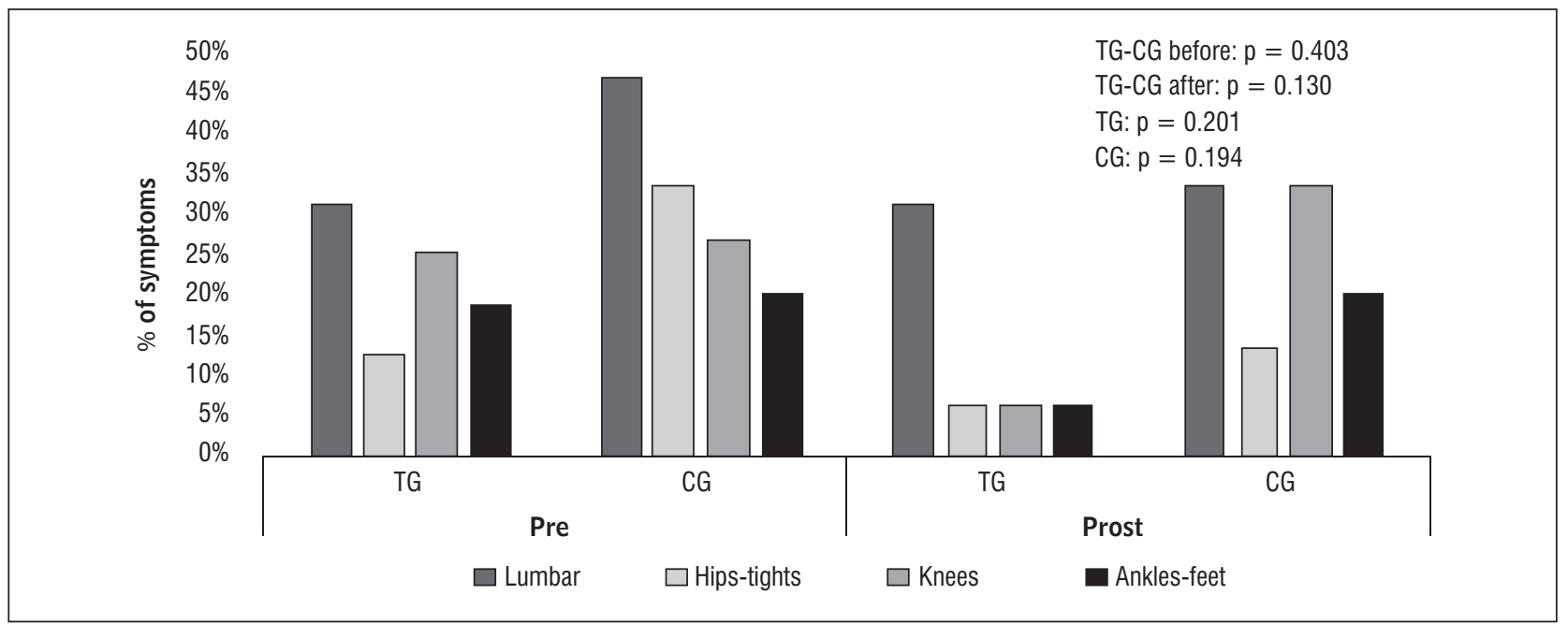

Figure 3 - Relative frequencies of symptoms in different body regions of the teachers from the TG and the CG group Note: TG-CG before = intergroup analysis before training; TG-CG after = intergroup analysis after training; TG = intra-group analysis; $\mathrm{CG}=$ intra-group analysis.

These data corroborate to the study of Kraemer et al. (22) reporting that the gain in muscle strength differs between trained and untrained individuals. When it is trained for a period of four weeks to one year, muscle strength increases $40 \%$ in untrained individuals, $20 \%$ in moderately trained individuals, $16 \%$ in trained individuals, $10 \%$ in advanced and $2 \%$ in elite athletes.

In this study there was no change in either the quadriceps and hamstrings peak torque. However, the gain obtained in muscle strength in this research confirms the results found in other studies, which prioritized exercises at the workplace to reduce musculoskeletal symptoms in workers. Although, these studies emphasized strength training rather than muscular endurance training, and the intensity proposed was relative to the percentage of 1 repetition maximum (1RM) as follow: Sjögren et al. $(3,23)$ used a load of $30 \%$ of 1RM; Andersen et al. (1), Jay et al. (5), Pedersen et al. (24) used $70-80 \%$ of $1 \mathrm{RM}$ and Zebis et al. (6) conducted training between 70-85\% of $1 \mathrm{RM}$. In this study, it was used $50-60 \%$ of $10 \mathrm{RM}$ muscular endurance training for seven weeks. Thus, it is suggested that muscular endurance exercises can 
be applied to patients with musculoskeletal symptoms in the lumbar region and lower limbs, providing gains in muscle strength.

With respect to work-related musculoskeletal symptoms, the higher incidence of symptoms was observed in the lower back, as was detected in other studies $(1,4,24)$.

Exercises carried out at the workplace can promote reduce the musculoskeletal symptoms (24). Sjögren et al. (3) observed the reduction of low back pain in office workers who performed resistance exercises ( 3 sets of 20 repetitions) for knee flexion and extension and trunk rotation, once a day, in the first five weeks, and also when these exercises were practiced once or twice a day for other ten weeks. Pedersen et al. (24) found a decrease in the frequency of weekly pain in the lower back and shoulders in public service employees, both in the group that performed exercise for upper limbs, three times weekly for $20 \mathrm{~min}, 2-3$ sets of $10-15$ repetitions at $70-80 \%$ $1 \mathrm{RM}$, and in the group that performed several types of aerobic and strength exercises, not specific to regions of the body, for one year. Thus, it can be assumed that beyond the training period, the weekly frequency also affects the response of exercise on pain.

Despite of these studies, there is no consensus on the type of exercise, load, number of repetitions and even on the weekly frequency. In addition, these studies were conducted on populations with different characteristics from the group assessed in the current research. Nevertheless, Coury et al. (25) observed that workplace exercises involving some form of physical resistance, like dumbbells, isokinetic equipment, elastic bands and anti-gravity exercises are effective in controlling musculoskeletal pain in the lumbar and cervical regions.

Although it was not found studies investigating the effects of exercise programs in symptoms related to work in the lower limbs, Yahia et al. (26) reported that the weakness of the quadriceps and hamstring muscles is associated with symptoms in the lumbar region and lower limbs. The strength imbalance between the flexor and extensor muscles of the knee joint can cause muscle-tendon overload, which amends joint stability and pelvic alignment producing muscle or joint pain in the lower limbs and lumbar region $(26,27)$.

The quadriceps muscle group is necessary for shock absorption, reducing the stress on the spine and knees. This means that stronger quadriceps have greater shock absorption capability transferring less stress to the spine, and thus preventing musculoskeletal symptoms in the lumbar region (28). Individuals with symptoms in the lumbar region present great inhibition of the quadriceps muscle, even without injury and muscle fatigue $(28,29)$. However, in this study there was an increase in muscle strength, but not in peak torque in the TG.

Thus, it can be hypothesized that the muscular endurance training of this study did not ameliorate the presence of musculoskeletal symptoms in the lower back region and the lower limbs, probably because it did not increase the peak torque the hamstrings and quadriceps, despite the increase in muscle strength of both muscle groups.

The outcomes of this study show that the local muscular endurance training, carried out twice a week, for seven weeks, promotes greater muscle strength of the quadriceps and hamstrings, in spite of it did not decrease the incidence of musculoskeletal symptoms in the lower back region and the lower limbs of teachers. Thus, it can be suggested that the exercises should be performed with resistance, with frequencies more than twice a week and training periods greater than seven weeks.

The assessment and training instruments used in this study were consistent with the local reality; the protocol established was easy to apply and was cost effective; and it provided an opportunity for teachers to practice physical activity in their workplace. For future studies, we suggest the mapping of musculoskeletal symptoms with an algometer; the investigation of neural gains by electromyography; and the measurement of the cross-sectional area of the muscles by magnetic resonance imaging, allowing the investigation of possible hypertrophic gains.

Although no direct evaluation of muscle length was performed, it can be inferred that the local muscular endurance training in this study did not improve the presence of musculoskeletal symptoms in the lower back region and lower limbs by having a possible relationship with muscle length. Therefore, it also suggests that further studies should be carried out to control this parameter.

\section{Conclusions}

The teachers participating in this study had a high incidence of musculoskeletal symptoms in the lower 
back region. The exercise program for local muscular endurance, held twice a week, for seven weeks, in their work environment, increased dynamic muscle strength in the training group compared to the control group, but it did not alter the incidence of symptoms in the lower back region and lower limbs, and there was no increase in peak torque in either group. Thus, it is suggested that the improvement in these symptoms are not only related to the gain in strength, but also associated with the increase in peak torque. Therefore, it is suggested that futures studies should be carried out with higher weekly frequency and longer period of training, investigating muscle architecture, neuromuscular aspects and inflammatory mediators.

\section{Acknowledgements}

We would like to thank the CNPq (National Research Council) for the assistance provided related to the research presentation rate and productivity grant of Prof. Anna Raquel Silveira Gomes (PhD) and scientific student initiation grant for the Physical Therapy course. Also, we would like to thank the teachers of the elementary schools from the municipality of Matinhos, Paraná, for their collaboration in this study, and all the teams from participating schools and the municipal office of education in Matinhos, Paraná.

\section{References}

1. Andersen LL, Christensen KB, Holtermann A, Poulsen OM, Sjogaard G, Pedersen MT, et al. Effect of physical exercise interventions on musculoskeletal pain in all body regions among office workers: a one-year randomized controlled trial. Man Ther. 2010;15(1):1004. doi:10.1016/j.math.2009.08.004.

2. Fernandes MH, Rocha VM, Costa-Oliveira AGR. Fatores associados à prevalência de sintomas osteomusculares em professores. Rev Saúde Pública. 2009;11(2):25667. doi:10.1590/S0124-00642009000200010.

3. Sjögren T, Nissinen KJ, Jarvenpaa SK, Ojanen MT, Vanharanta H, Malkia EA. Effects of a workplace physical exercise intervention on the intensity of low back symptoms in office workers: a cluster randomized controlled cross-over design. J Back and Musculoskelet Rehab. 2006;19(1):13-24.
4. Marangoni AH. Effects of intermittent stretching exercises at work on musculoskeletal pain associated with the use of a personal computer and the influence of media on outcomes. Work. 2010;36(1):27-37. doi: 10.3233/WOR-2010-1004.

5. Jay K, Frisch D, Hansen K, Zebis MK, Andersen CH, Mortensen OS, et al. Kettlebell training for musculoskeletal and cardiovascular health: A randomized controlled trial. Scandin J Work Environ Health. 2011;37(3):196-203. doi: 10.5271/sjweh.3136.

6. Zebis MK, Andersen LL, Pedersen MT, Mortensen P, Andersen $\mathrm{CH}$, Pedersen MM, et al. Implementation of neck/shoulder exercises for pain relief among industrial workers: a randomized controlled trial. BMC Musculoskelet Disord. 2011;12:205. doi: 10.1186/1471-2474-12-205.

7. Brito WF, Santos CL, Marcolongo AA, Campos MD, Bocalini DS, Antonio EL, et al. Nível de atividade física em professores da rede estadual de ensino. Rev Saúde Pública. 2012;46(1):104-9. doi: 10.1590/ S0034-89102012000100013.

8. Thomas JR, Nelson JK, Silverman SJ. Métodos de pesquisa em atividade física. Porto Alegre: Artmed; 2007.

9. Brasil. Ministério da Saúde. Secretaria de Atenção à Saúde. Departamento de atenção básica. Antropometria: como pesar e medir. Brasília: MS; 2004 [cited 2012 Sept 12]. Available from: http://bvsms.saude.gov.br/ bvs/publicacoes/orientacoes_basicas_sisvan.pdf

10. World Health Organization. Obesity: preventing and managing the global epidemic. Report of the WHO Consultation of Obesity. Geneva: World Health Organization; 1997 [cited 2011 Apr 4]. Available from: http://www.who.int/nutrition/publications/obesity_executive_summary.pdf

11. Sociedade Brasileira de Cardiologia; Sociedade Brasileira de Hipertensão; Sociedade Brasileira de Nefrologia. VI Diretrizes brasileiras de hipertensão. Arq Bras Cardiol. 2010;95(Supl. 1):1-51. doi.org/10.1590/ S0066-782X2010001700001.

12. Malfatti CA, Rodrigues SY, Takahashi ACM, Silva E, Menegon FA, Mattiello-Rosa SM, et al. Análise da resposta da frequência cardíaca durante a realização de exercício isocinético excêntrico de grupamento extensor de joelho. Rev Bras Fisioter. 2006;10(1):51-7. doi. org/10.1590/S1413-35552006000100007. 
13. Simão R, Polito M, Monteiro W. Efeito de diferentes intervalos de recuperação em um programa de treinamento de força para indivíduos treinados. Rev Bras Med Esporte. 2008;14(4):353-8. doi.org/10.1590/ S1517-86922008000400006.

14. Baechle TR, Earle RW. Essentials of strength training and conditioning. Champaign: Human Kinectics; 2008.

15. Loureiro S, Dias I, Sales D, Alessi I, Simão R, Fermino RC. Efeito das diferentes fases do ciclo menstrual no desempenho da força muscular em 10RM. Rev Bras Med Esporte. 2011;17(1):22-25. doi.org/10.1590/ S1517-86922011000100004.

16. Bento PCB, Pereira G, Ugrinowitsch C, Rodacki ALF. Peak torque and rate of torque development in elderly with and without fall history. Clin Biomech. 2010;25(5):450-4. doi: 10.1016/j. clinbiomech.2010.02.002.

17. Barros ENC, Alexandre NMC. Cross-cultural adaptation of the Nordic musculoskeletal questionnaire. Intern Nurs Review. 2003;50(2):101-8.

18. Woods K, Bishop P, Jones E. Warm-up and stretching in the prevention of muscular injury. Sports Med. 2007;37(12):1089-99. doi: 0112-1642/07/0012-1089.

19. Bandy WD, Sanders B. Exercício terapêutico: técnicas para intervenção. Rio de Janeiro: Guanabara Koogan; 2003.

20. Kraemer WJ, Ratamess NA. Fundamentals of resistance training: progression and exercise prescription. Med Sci Sports Exerc. 2004;36(4):674-88. doi: 10.1249/01.MSS.0000121945.36635.61.

21. Reis GM, Ribeiro Júnior JI. Comparação de testes paramétricos e não paramétricos aplicados em delineamentos experimentais . Anais da 3. Semana Acadêmica de Engenharia de Produção; 2007, Viçosa. MG, Brasil. p. 1-13.

22. Kraemer WJ, Adams K, Cafarelli E, Dudley GA, Dooly C, Feigenbaum MS, et al. American College of Sports Medicine position stand. Progression models in resistance training for healthy adults. Med Sci Sports Exer. 2002;34(2):364-80. doi: 0195-9131/02/3402-0364/0.
23. Sjögren T, Nissinen KJ, Järvenpää SK, Ojanen MT, Vanharanta H, Malkia EA. Effects of a workplace physical exercise intervention on the intensity of headache and neck and shoulder symptoms and upper extremity muscular strength of office workers: a cluster randomized controlled cross-over trial. Pain. 2005;116(1-2):119-28.

24. Pedersen MT, Blangsted AK, Andersen LL, Jorgensen MB, Hansen EA, Sjogaard G. The effect of worksite physical activity intervention on physical capacity, health, and productivity: a 1-year randomized controlled trial. J Occup Environ Med. 2009;51(7):759-70. doi: 10.1097/JOM.0b013e3181a8663a.

25. Coury HJCG, Moreira RFC, Dias NB. Efetividade do exercício físico em ambiente ocupacional para controle da dor cervical, lombar e do ombro: uma revisão sistemática. Rev Bras Fisioter. 2009;13(6):461-79. doi. org/10.1590/S1413-35552009000600002.

26. Yahia A, Jribi S, Ghroubi S, Elleuch M, Baklouti S, Elleuch MH. Evaluation of the posture and muscular strength of the trunk and inferior members of patients with chronic lumbar pain. Joint Bone Spine. 2011;78(3):291-7. doi: 10.1016/j.jbspin.2010.09.008.

27. Polachini LO, Fusazaki L, Tamaso M, Tellini GG, Masiero D. estudo comparativo entre três métodos de avaliação do encurtamento de musculatura posterior de coxa. Rev Bras Fisioter. 2005;9(2):187-93.

28. Hart JM, Weltman A, Ingersoll CD. Quadriceps activation following aerobic exercise in persons with low back pain and healthy controls. Clin Biomech. 2010;25(8):847-51. doi: 10.1016/j. clinbiomech.2010.05.009.

29. Suter E, Lindsay D. Back muscle fatigability is associated with knee extensor inhibition in subjects with low back pain. Spine. 2001;26(16):361-6.

Received: 07/31/2013

Recebido: 31/07/2013

Approved: 04/07/2015 Aprovado: 07/04/2015 